\title{
Volatile Constituents of Mold-Susceptible and Mold-Resistant Sorghum [Sorghum bicolor (L.) Moench] Grains ${ }^{\dagger}$
}

\author{
Ramamurthi Jambunathan* \\ Department of Food Science and Animal Industries, Alabama A\&MI University, Normal, Alabama 35762 \\ Milind S. Kherdekar, Kooram Raghunath, and Vaidyanathan Subramanian \\ Crop Quality Unit, International Crops Research Institute for the Semi-Arid Tropics (ICRISAT), \\ Patancheru, Andhra Pradesh 502 324, India
}

\begin{abstract}
Headspace volatile compounds of mold-susceptible and mold-resistant sorghum [Sorghum bicolor (L.) Moench] grains were determined. The concentrations of volatile compounds in mold-susceptible sorghum were higher than those of mold-resistant sorghum. Among the 10 compounds that were identified, 2-methylbutanal was severalfold higher in the mold-susceptible sorghum than in the mold-resistant sorghum. A comparison of volatile compounds of mold-susceptible grains obtained from greenhouse-grown sorghum (mold-free) with those of field-grown sorghum indicated the possibility of a large contribution of volatile compounds from fungal organisms.
\end{abstract}

\section{Keywords: Sorghum headspace volatiles; sorghum flavor compounds; sorghum grain mold}

\section{INTRODUCTION}

Volatile compounds of fungi impart musty, earthy, and other unpleasant odors and are associated with spoilage of foods and grains (Karahadian et al., 1985). Fusarium moniliforme contaminated grains have been implicated in causing leucoencephalomalacia in horses, esophageal cancer in humans, and hepatocarcinomas in ducks and mice (Jackson et al., 1990). Fungal volatiles have been used to characterize different strains of fungi (Seifert and King, 1982). Borjesson et al. (1989) identified the major volatile fungal metabolites as 2-methylfuran, 2-methyl-1-propanol, and 3-methyl-1-butanol during fungal growth on wheat (Triticum aestivum $\mathrm{L}$. em Thell). High-performance liquid chromatography was used to purify and measure the potent mutagen fusarin $C$ from cultures of $F$. moniliforme (Jackson et al., 1990). Another mycotoxin, fumonisin, from corn (Zea mays L.) cultures of $F$. moniliforme is implicated in toxicological and carcinogenic effects in animals and humans (Sydenham et al., 1991).

Sorghum grain mold is caused by $F$. moniliforme (Sheld.), Curvularia lunata (Wakker) Boedijn, and Phoma sorghina (Sacc.) Boerma et al. (Jambunathan et al., 1990). Mold problems are widespread in the semiarid tropical regions. Human consumption of grains infested with mold should therefore be a concern. The development of mold-resistant sorghum cultivars is therefore important in relation to yield, utilization, and economic value of this crop.

We have earlier analyzed mold-susceptible and moldresistant sorghum grains for polyphenolic compounds, and the positive association of flavan-4-ols in grain and leaf was established with mold resistance (Jambunathan et al., 1986, 1990; Jambunathan and Kherdekar, 1991). Ergosterol is an essential constituent of fungal biomass, and its determination gives an assessment of mold incidence in the grain. Ergosterol was found to

† Submitted as Journal Article 1567 by ICRISAT and contributed by the Agricultural Experiment Station, Alabama A\&M University, Journal Article T 235. be significantly and negatively correlated $(r=-0.50, P$ $<0.01$ ) with flavan-4-ols in sorghum grains (Jambunathan et al., 1991) and with sorghum grain hardness $(r=-0.78, P<0.01)$, indicating positive association of grain hardness with grain mold resistance (Jambunathan et al., 1992).

Volatile compounds of mold-resistant and moldsusceptible sorghum grains have not been investigated. The objective of the present study was to identify and compare the concentrations of volatile compounds in mold-resistant and mold-susceptible sorghum grains.

\section{EXPERIMENTAL PROCEDURES}

Agronomy. Ten sorghum germplasm accessions and three breeding lines resistant and susceptible to grain mold were grown during the 1990 rainy season on a Vertisol at the International Crops Research Institute for the Semi-Arid Tropics (ICRISAT), Patancheru, Andhra Pradesh, India. The germplasm and breeding lines were selected on the basis of their phenotypic white (W) or colored (C) grain color (Munsell Book of Color, 1989), their reaction to grain mold ( $R$ or $S$ ), the presence $\left(\mathrm{T}^{+}\right)$or absence $\left(\mathrm{T}^{-}\right)$of testa, and threshed grain mold ratings (TGMR) (Table 1 ). They were planted in a randomized complete block design with three replications. The details of the planting plan were as described earlier (Jam. bunathan et al., 1990). The developing sorghum panicles were tagged at $50 \%$ flowering and harvested 14 days after maturity and threshed. Three panicles from each replicate were harvested, and the grains from these panicles were pooled. Grains were stored at $4^{\circ} \mathrm{C}$ prior to analysis.

Headspace Volatiles. Sorghum meal samples were analyzed for their headspace volatiles according to the method of Young and Hovis (1990) with the following modifications. Sorghum grains [ 10 germplasm accessions and 3 breeder lines (Table 1), each from 3 field replicates] were ground in a Udy mill (U.D. Corp., Boulder, CO) using a $0.4 \mathrm{~mm}$ sieve. About $1.5 \mathrm{~g}$ of ground sample was accurately weighed for analysis. A gas chromatograph (GC), Shimadzu GC 9A, fitted with a flame ionization detector and a glass column $(1 \mathrm{~m} \times 2 \mathrm{~mm}$ i.d.) packed with Porapak $P(80-100$ mesh) (porous beads of methylvinylbenzene copolymer from Alltech Associates Inc.) was used. Flow of the carrier gas helium was adjusted to 65 $\mathrm{mL} / \mathrm{min} 80$ that hexanal eluted at $5.00 \pm 0.03 \mathrm{~mL} / \mathrm{min}$. The 
Table 1. Description of Sorghum Accessions and Breeding Linej, Grain Colory Muneell Color Coding, and Thireshed Grain Mold Rating (TGMR)

\begin{tabular}{|c|c|c|c|c|}
\hline groupe & accession/breeding line & grain color & Munsell color coding & TGMRe \\
\hline $\begin{array}{l}\mathrm{CRT}^{+} \text {(colored, } \\
\text { resistant, } \\
\text { with testa) }\end{array}$ & $\begin{array}{l}\text { IS } 625 \\
\text { IS } 9353 \\
\text { IS } 18759\end{array}$ & $\begin{array}{l}\text { reddish brown } \\
\text { brown } \\
\text { reddish brown }\end{array}$ & $\begin{array}{l}2.5 Y R / 3 / 3 \\
2.5 Y R / 4 / 4 \\
2.5 Y R / 3 / 4\end{array}$ & $\begin{array}{l}2.0 \pm 0 \\
2.0 \pm 0 \\
2.0 \pm 0\end{array}$ \\
\hline $\begin{array}{l}\text { CST- (colored, } \\
\text { susceptible, } \\
\text { without testa) }\end{array}$ & $\begin{array}{l}\text { IS } 402 \\
\text { IS } 417\end{array}$ & $\begin{array}{l}\text { reddish yellow } \\
\text { reddish yellow }\end{array}$ & $\begin{array}{l}5 \mathrm{YR} / 6 / 8 \\
5 \mathrm{YR} / 6 / 8\end{array}$ & $\begin{array}{l}4.8 \pm 0.03 \\
4.8 \pm 0.03\end{array}$ \\
\hline $\begin{array}{l}\text { CRT }^{-} \text {(colored } \\
\text { resistant, } \\
\text { without testa) }\end{array}$ & $\begin{array}{l}\text { IS } 14375 \\
\text { IS } 14380 \\
\text { IS } 14384\end{array}$ & $\begin{array}{l}\text { red } \\
\text { red } \\
\text { red }\end{array}$ & $\begin{array}{l}2.5 Y R / 4 / 8 \\
2.5 \mathrm{YR} / 5 / 6 \\
2.5 \mathrm{YR} / 4 / 8\end{array}$ & $\begin{array}{l}1.8 \pm 0.10 \\
1.9 \pm 0.13 \\
2.0 \pm 0\end{array}$ \\
\hline $\begin{array}{c}\text { WST }^{+} \text {(white, } \\
\text { susceptible, } \\
\text { with testa) }\end{array}$ & $\begin{array}{l}\text { IS } 2433 \\
\text { IS } 2516\end{array}$ & $\begin{array}{l}\text { white } \\
\text { white } \\
\text {. }\end{array}$ & $\begin{array}{l}10 \mathrm{YR} / 8 / 1 \\
10 \mathrm{YR} / 8 / 1\end{array}$ & $\begin{array}{l}5.0 \pm 0 \\
5.0 \pm 0\end{array}$ \\
\hline $\begin{array}{l}\text { WRT- (white, } \\
\text { resistant, } \\
\text { without testa) }\end{array}$ & $\begin{array}{l}\text { B } 48826 \\
\text { B } 48890 \\
\text { B } 48971\end{array}$ & $\begin{array}{l}\text { yellowish white } \\
\text { yellowish white } \\
\text { yellowish white }\end{array}$ & $\begin{array}{l}7.5 Y / 9 / 2 \\
7.5 Y / 8.5 / 2 \\
5 Y / 9 / 2\end{array}$ & $\begin{array}{l}2.0 \pm 0 \\
1.9 \pm 0.03 \\
2.1 \pm 0.03\end{array}$ \\
\hline
\end{tabular}

a Based on phenotypic grain color, reaction to mold, and presence or absence of testa. ${ }^{b}$ Munsell color coding denotes the hue (first value), color (second value), and chorma (third value), respectively. Y, yellow, YR, yellow red. ${ }^{c} 1$, No mold; 5 , more than $50 \%$ of grain surface molded. Mean $\pm \mathrm{SE}$ of 30 observations.

column temperature was programmed to increase from 105 to $225^{\circ} \mathrm{C}$ at $15^{\circ} \mathrm{C} / \mathrm{min}$ and was held at $225^{\circ} \mathrm{C}$ for $0.5 \mathrm{~min}$. The injector and detector ports were maintained at $240^{\circ} \mathrm{C}$. The volatile compounds were tentatively identified by spiking the sorghum flour with each of the reference compounds separately, and their retention times and areas were noted. The GC patterns of 10 individual volatile compounds, namely, methanol (Fisher Scientific Co.), acetaldehyde, methyl acetate, 2-methylpropanal, 2-butanone, 2-methylbutanal, and $N$-methylpyrrole (Aldrich Chemical Co.), hexanal and pentanal (Sigma Chemical Co.), and acetone (Fisher) were also obtained to determine their retention times. These 10 volatile com. pounds were then tentatively identified in mold-susceptible and mold-resistant sorghum grains, and their concentrations were recorded as nanomole equivalents of acetone.

To compare the volatile compounds of field-grown sorghums with that of greenhouse-grown sorghum, IS 14384 belonging to the $\mathrm{CRT}^{-}$group, IS 402 belonging to the CST- group, and a breeding line $\mathrm{B} 48890$ belonging to the WRT- group were grown in a greenhouse under controlled conditions to minimize grain mold attack. The headspace volatiles of these grain samples were determined by GC as described above.

Ergosterol. The concentration of ergosterol in sorghum grain samples was determined by HPLC (Jambunathan et al., 1991).

All analyses were conducted in duplicate on each of the field replications. Mean values are reported. Correlations were calculated using the Genstat 4.04 software program (Rothamsted Experimental Station, Hertfordshire, U.K.).

\section{RESULTS AND DISCUSSION}

The concentrations of volatile compounds in grain samples in different groups are expressed as nanomole equivalents of acetone, and their significant differences using the Waller-Duncan $K$ ratio test (Shane et al., 1990) are shown in Table 2. The concentration of 2-methylpropanal in the CST- group was significantly higher $(P<0.01)$ than the concentration obtained in the resistant groups (CRT-, $\mathrm{CRT}^{+}$, and WRT-). Similarly, the concentration of 2-methylbutanal in the CSTgroup was significantly $(P<0.01)$ higher than the concentration obtained in the resistant groups (CRT'-, $\mathrm{CRT}^{+}$, and WRT ${ }^{-}$). This indicated a clear distinction between mold-resistant groups $\mathrm{CRT}^{+}, \mathrm{CRT}^{-}$, and WRTand the mold-susceptible group CST- for 2-methylpropanal and 2-methylbutanal. Also, statistically significant $(P<0.01)$ differences were observed between these two groups for all seven volatile compounds and total volatile compounds. The concentration of volatile compounds 2-methylbutanal and hexanal was significantly higher in the WST ${ }^{+}$group as compared to that in the three resistant groups.

Table 2 shows that volatile compounds were 1-6 times higher in the CST- group as compared with the three resistant $\mathrm{CRT}^{-}, \mathrm{WRT}^{-}$, and $\mathrm{CRT}^{+}$groups. 2Methylbutanal was 4-6-fold higher in the CST- group as compared with the $\mathrm{CRT}^{+}, \mathrm{CRT}^{-}$, and $\mathrm{WRT}^{-}$groups, indicating that the concentration of 2-methylbutanal could be a sensitive and good indicator for its association with grain mold resistance or susceptibility. 2-Methylpropanal also exhibited clear differences between the susceptible and resistant groups. The ratios obtained with the $\mathrm{WST}^{+}$group with respect to the $\mathrm{CRT}^{+}, \mathrm{CRT}^{-}$, and WRT $^{-}$groups also presented a similar trend for 2-methylbutanal, though the fold differences were lower when compared to that of the CST- group.

The concentration of ergosterol is a quantitative measure of fungi in the grains (Seitz et al., 1979). Our earlier experiment showed that ergosterol concentrations in the $\mathrm{CST}^{-}$and $\mathrm{WST}^{+}$groups were at least 10 times that of $\mathrm{CRT}^{+}, \mathrm{CRT}^{-}$, and $\mathrm{WRT}^{-}$in the mature grains (Jambunathan et al., 1991). Correlation coefficients $(D F=76$ ) obtained between the concentration of ergosterol and individual volatile compounds are shown in Table 3. Several volatile compounds exhibited positive and significant correlations with ergosterol, and these volatile constituents may be related to mold attack. Seifert and King (1982) observed that closely related fungi have different volatile compositions that can be used to distinguish them from each other. For this purpose individual fungal organisms that are reported to be associated with grain mold should be studied to understand their role in producing volatile compounds.

Effect of Environment. The grain samples obtained from the greenhouse were almost mold-free since only negligible concentrations of ergosterol (IS 402, 1.9 $\mu \mathrm{g} / \mathrm{g}$; IS 14384, IS 18759 , and B 48890, ergosterol not detected) could be detected. The headspace analyses of greenhouse-grown sorghum grain samples were compared with that of corresponding samples grown in the field (Table 4). The concentrations of volatile compounds in the field-grown samples were higher than that of greenhouse samples for the mold-susceptible 
Table 2. Concentrations (Nanomoles of Acetone Equivalents) of Identified Volatne Compounds in Field-Grown Mold-Resistant and Mold-Susceptible Sorghum Grains"

\begin{tabular}{|c|c|c|c|c|c|c|c|c|c|c|}
\hline group & $\begin{array}{l}\text { accession/ } \\
\text { breeding line }\end{array}$ & $\begin{array}{l}\text { ergosterol } \\
\left(\mu \mathrm{g} \mathrm{g}^{-1}\right)\end{array}$ & acetaldehyde & acetone & $\begin{array}{l}\text { 2-methyl- } \\
\text { propanal }\end{array}$ & 2-butanone & $\begin{array}{l}\text { 2-methyl- } \\
\text { butanal }\end{array}$ & pentanal & hexanal & $\begin{array}{c}\text { total } \\
\text { volatiles }\end{array}$ \\
\hline $\mathrm{CRT}^{+}$ & $\begin{array}{l}\text { IS } 625 \\
\text { IS } 9353 \\
\text { IS } 18759 \\
\text { mean } \\
\text { SE } \pm \\
\text { CV }\end{array}$ & $\begin{array}{l}18.0 \\
16.0 \\
13.6 \\
15.9 \mathrm{a} \\
1.29 \\
24.3\end{array}$ & $\begin{array}{c}34.4 \\
21.7 \\
26.6 \\
27.6 \mathrm{c} \\
1.43 \\
21.9\end{array}$ & $\begin{array}{c}13.4 \\
6.5 \\
7.8 \\
9.3 \mathrm{c} \\
0.78 \\
35.6\end{array}$ & $\begin{array}{c}7.7 \\
5.5 \\
7.4 \\
6.8 \mathrm{~d} \\
0.31 \\
19.1\end{array}$ & $\begin{array}{l}3.0 \\
1.6 \\
1.9 \\
2.2 \mathrm{~d} \\
0.16 \\
31.6\end{array}$ & $\begin{array}{c}8.3 \\
7.2 \\
7.9 \\
7.8 \mathrm{c} \\
0.33 \\
18.2\end{array}$ & $\begin{array}{l}4.4 \\
2.4 \\
2.7 \\
3.2 \mathrm{c} \\
0.24 \\
31.7\end{array}$ & $\begin{array}{l}3.7 \\
2.4 \\
2.7 \\
2.9 \mathrm{c} \\
0.17 \\
24.9\end{array}$ & $\begin{array}{c}84.4 \\
53.1 \\
63.4 \\
67.0 \mathrm{~d} \\
3.62 \\
22.9\end{array}$ \\
\hline $\mathrm{CST}^{-}$ & $\begin{array}{l}\text { IS } 402 \\
\text { IS } 417 \\
\text { mean } \\
\text { SE } \pm \\
\text { CV }\end{array}$ & $\begin{array}{c}107.8 \\
73.7 \\
90.8 \mathrm{~b} \\
14.62 \\
39.4\end{array}$ & $\begin{array}{l}51.1 \\
50.0 \\
50.7 \mathrm{a} \\
3.73 \\
23.3\end{array}$ & $\begin{array}{l}16.8 \\
17.6 \\
17.2 \mathrm{a} \\
1.37 \\
25.2\end{array}$ & $\begin{array}{c}23.9 \\
31.0 \\
26.8 \mathrm{a} \\
3.64 \\
43.0\end{array}$ & $\begin{array}{l}4.2 \\
4.0 \\
4.1 \mathrm{a} \\
0.38 \\
29.5\end{array}$ & $\begin{array}{l}44.5 \\
49.3 \\
46.4 \mathrm{a} \\
6.50 \\
44.3\end{array}$ & $\begin{array}{l}6.8 \\
5.4 \\
6.3 \mathrm{a} \\
0.60 \\
30.4\end{array}$ & $\begin{array}{c}8.2 \\
6.2 \\
7.4 a \\
0.69 \\
29.4\end{array}$ & $\begin{array}{c}169.3 \\
176.1 \\
172.0 \mathrm{a} \\
17.22 \\
\$ 1.7\end{array}$ \\
\hline $\mathrm{CRT}^{-}$ & $\begin{array}{l}\text { IS } 14375 \\
\text { IS } 14380 \\
\text { IS } 14384 \\
\text { mean } \\
\text { SE } \pm \\
\text { CV }\end{array}$ & $\begin{array}{c}25.8 \\
23.8 \\
28.0 \\
25.9 \mathrm{~b} \\
2.53 \\
29.3\end{array}$ & $\begin{array}{l}32.1 \\
42.2 \\
30.0 \\
34.7 \mathrm{bc} \\
2.24 \\
27.4\end{array}$ & $\begin{array}{c}10.4 \\
15.4 \\
9.7 \\
11.8 b c \\
0.82 \\
29.5\end{array}$ & $\begin{array}{l}6.8 \\
8.7 \\
6.3 \\
7.3 \mathrm{~cd} \\
0.47 \\
27.6\end{array}$ & $\begin{array}{l}2.5 \\
3.3 \\
2.3 \\
2.7 \mathrm{~cd} \\
0.15 \\
23.7\end{array}$ & $\begin{array}{c}6.9 \\
9.5 \\
6.5 \\
7.6 \mathrm{c} \\
0.54 \\
30.0\end{array}$ & $\begin{array}{l}4.0 \\
4.7 \\
3.5 \\
4.1 \mathrm{bc} \\
0.23 \\
23.8\end{array}$ & $\begin{array}{c}4.8 \\
5.3 \\
4.1 \\
4.7 \mathrm{~b} \\
0.21 \\
19.2\end{array}$ & $\begin{array}{c}75.9 \\
100.3 \\
69.3 \\
81.8 \mathrm{~cd} \\
5.04 \\
26.2\end{array}$ \\
\hline $\mathrm{WST}^{+}$ & $\begin{array}{l}\text { IS } 2433 \\
\text { IS } 2516 \\
\text { mean } \\
\text { SE士 } \\
\text { CV }\end{array}$ & $\begin{array}{c}268.5 \\
127.3 \\
197.9 \mathrm{e} \\
34.6 \\
42.8\end{array}$ & $\begin{array}{l}33.1 \\
29.0 \\
31.1 \mathrm{~b} \\
1.09 \\
12.2\end{array}$ & $\begin{array}{c}15.0 \\
11.6 \\
13.3 \mathrm{~b} \\
0.67 \\
17.5\end{array}$ & $\begin{array}{c}14.6 \\
12.2 \\
13.4 \mathrm{~b} \\
0.62 \\
16.1\end{array}$ & $\begin{array}{l}4.9 \\
2.4 \\
3.7 \mathrm{ab} \\
0.42 \\
39.4\end{array}$ & $\begin{array}{c}24.0 \\
19.8 \\
21.9 \mathrm{~b} \\
1.07 \\
16.9\end{array}$ & $\begin{array}{l}6.2 \\
4.3 \\
5.3 \mathrm{ab} \\
0.32 \\
20.8\end{array}$ & $\begin{array}{l}8.8 \\
5.5 \\
7.2 \mathrm{a} \\
0.54 \\
31.6\end{array}$ & $\begin{array}{c}122.5 \\
93.7 \\
108.1 \mathrm{~b} \\
5.05 \\
16.2\end{array}$ \\
\hline WRT $^{-}$ & $\begin{array}{l}\text { B } 48826 \\
\text { B } 48890 \\
\text { B } 48971 \\
\text { mean } \\
\text { SE士 } \\
\text { CV }\end{array}$ & $\begin{array}{c}22.0 \\
28.4 \\
23.8 \\
24.7 \mathrm{~b} \\
1.77 \\
21.5\end{array}$ & $\begin{array}{c}52.8 \\
29.9 \\
29.1 \\
37.2 \text { b } \\
3.05 \\
34.9\end{array}$ & $\begin{array}{c}22.5 \\
9.2 \\
10.9 \\
14.2 \mathrm{ab} \\
1.58 \\
47.4\end{array}$ & $\begin{array}{c}16.5 \\
7.6 \\
8.4 \\
10.8 \text { bc } \\
1.15 \\
44.9\end{array}$ & $\begin{array}{l}4.9 \\
2.1 \\
2.5 \\
3.2 \mathrm{bc} \\
0.33 \\
43.9\end{array}$ & $\begin{array}{c}16.3 \\
7.1 \\
8.6 \\
10.7 \mathrm{c} \\
1.18 \\
46.8\end{array}$ & $\begin{array}{c}7.7 \\
3.6 \\
3.4 \\
4.9 \mathrm{~b} \\
0.55 \\
48.0\end{array}$ & $\begin{array}{l}7.8 \\
4.3 \\
4.0 \\
5.4 \mathrm{~b} \\
0.50 \\
39.3\end{array}$ & $\begin{array}{c}146.9 \\
70.9 \\
75.1 \\
97.6 \text { bc } \\
9.55 \\
41.5\end{array}$ \\
\hline
\end{tabular}

a Means with the same letter under each column do not differ significantly $(P<0.01)$ from each other (Waller-Duncan $K$ ratio test).

Table 3. Correlation Coefficients between the Concentration of Ergosterol and the Different Volatile Compounds

\begin{tabular}{ccccccc} 
& $\begin{array}{c}\text { 2-methyl- } \\
\text { propanal }\end{array}$ & 2-butanone & $\begin{array}{c}\text { 2-methyl- } \\
\text { butanal }\end{array}$ & pentanal & hexanal & $\begin{array}{c}\text { total } \\
\text { volatiles }\end{array}$ \\
\hline ergosterol & 0.34 & 0.46 & 0.43 & 0.33 & 0.56 \\
${ }^{\circ} \mathrm{DF}=76$. All values are significant $(P<0.01)$. & & &
\end{tabular}

Table 4. Concentrations (Nanomoles of Acetone Equivalents) of Identified Volatile Compounds in Greenhouse-Grown Mold-Resistant and Mold-Susceptible Sorghum Grains

\begin{tabular}{|c|c|c|c|c|c|c|c|c|c|c|}
\hline group & $\begin{array}{l}\text { accession/ } \\
\text { breeding line }\end{array}$ & $\begin{array}{c}\text { ergosterol } \\
\left(\mu \mathrm{g} \mathrm{g}^{-1}\right)\end{array}$ & acetaldehyde & acetone & $\begin{array}{l}\text { 2-methyl- } \\
\text { propanal }\end{array}$ & 2-butanone & $\begin{array}{l}\text { 2-methyl- } \\
\text { butanal }\end{array}$ & pentanal & hexanal & $\begin{array}{c}\text { total } \\
\text { volatiles }\end{array}$ \\
\hline $\mathrm{CRT}^{+}$ & $\begin{array}{l}\text { IS } 18759 \\
\text { SE } \pm\end{array}$ & $\mathrm{nd}^{a}$ & $\begin{array}{c}37.2 \\
0.55\end{array}$ & $\begin{array}{c}15.8 \\
0.37\end{array}$ & $\begin{array}{l}8.5 \\
0.16\end{array}$ & $\begin{array}{l}2.5 \\
0.04\end{array}$ & $\begin{array}{l}7.8 \\
0.17\end{array}$ & 2.6 & 2.5 & $\begin{array}{c}86.7 \\
1.29\end{array}$ \\
\hline $\mathrm{CST}^{-}$ & $\begin{array}{l}\text { IS } 402 \\
\mathrm{SE} \pm\end{array}$ & 1.9 & $\begin{array}{c}46.3 \\
1.18\end{array}$ & $\begin{array}{l}16.3 \\
1.21\end{array}$ & $\begin{array}{l}9.0 \\
0.35\end{array}$ & $\begin{array}{l}3.2 \\
0.09\end{array}$ & $\begin{array}{l}8.6 \\
0.39\end{array}$ & $\begin{array}{l}4.1 \\
0.02\end{array}$ & $\begin{array}{l}4.2 \\
0.09\end{array}$ & $\begin{array}{l}105.0 \\
3.75\end{array}$ \\
\hline $\mathrm{CRT}^{-}$ & $\begin{array}{l}\text { IS } 14384 \\
\text { SE } \pm\end{array}$ & nd & $\begin{array}{l}34.2 \\
1.10\end{array}$ & $\begin{array}{c}13.1 \\
0.04\end{array}$ & $\begin{array}{l}9.0 \\
1.80\end{array}$ & $\begin{array}{l}3.4 \\
1.10\end{array}$ & $\begin{array}{l}10.0 \\
1.95\end{array}$ & $\begin{array}{l}3.8 \\
0.50\end{array}$ & $\begin{array}{l}3.8 \\
0.28\end{array}$ & $\begin{array}{c}95.1 \\
6.68\end{array}$ \\
\hline WRT- & $\begin{array}{l}\text { B } 48890 \\
\text { SE士 }\end{array}$ & nd & $\begin{array}{c}31.1 \\
3.83\end{array}$ & $\begin{array}{c}13.7 \\
0.85\end{array}$ & $\begin{array}{l}5.9 \\
0.53\end{array}$ & $\begin{array}{l}2.6 \\
0.24\end{array}$ & $\begin{array}{l}5.0 \\
0.40\end{array}$ & $\begin{array}{l}4.4 \\
0.34\end{array}$ & $\begin{array}{l}5.3 \\
.0 .35\end{array}$ & $\begin{array}{c}79.6 \\
5.70\end{array}$ \\
\hline
\end{tabular}

and, not detected.

accession IS 402. For example, the concentrations of 2-methylpropanal and 2-methylbutanal were 3- and 5 -fold higher, respectively, in the field-grown samples when compared with the values obtained on the greenhouse-grown samples. The concentrations of the volatile compounds of the field-grown and greenhouse-grown samples of mold-resistant IS 14384 and B 48890 were comparable. This observation, though preliminary in nature, indicated that fungi could have contributed a substantial amount of volatile compounds in the moldsusceptible sorghum grains. Over 40 genera of fungi have been associated with grain mold (Castor and Frederikson, 1980). F . moniliforme (Sheld.), C. lunata (Wakker) Boedijn, and P. sorghina (Sacc.) Boerma are considered the most important. Therefore, the volatile compounds of each of the fungi that are reported to be associated with grain mold should be studied to understand the similarities and differences in their nature and concentration of volatile compounds. Interactive influences of the volatile compounds on field-grown sorghum samples would be useful information also.

Conclusions. The concentrations of volatile compounds in the mold-susceptible sorghum are much higher than those of mold-resistant sorghum. Among the volatile compounds, the concentrations of 2-methylbutanal were significantly different between moldsusceptible and mold-resistant sorghums. The concentration of 2-methylbutanal in the molded grains may be useful to assess the quality of grains for human consumption. 
Analyses for 2-methylbutanal could possibly be another tool to detect various degrees of mold attack in addition to flavan-4-ols and grain hardness (Jambunathan et a.., 1991, 1992). Preliminary analysis of greenhouse-grown samples indicates the possible influence of fungal organisms in releasing the volatile compounds in the mold-susceptible sorghum grains. The influence of each of the fungal organisms and their relative role in contributing to volatile compounds need further investigation.

\section{ACKNOWLEDGMENT}

We thank Y. L. Nene for his suggestions and interest. We thank the Sorghum Breeding Unit for providing the samples.

\section{LITERATURE CITED}

Borjesson, T.; Stollman, U.; Adamek, P.; Kaspersson, A. Analysis of volatile compounds for detection of molds in stored cereals. Cereal Chem. 1989, 66, 300-304.

Castor, L. L.; Frederiksen, R. A. Fusarium and Curvularia grain molds in Texas. In Proceedings of the International Workshop on Sorghum Diseases, sponsored jointly by Texas A\&M University and ICRISAT, Dec 11-15, 1978, Hyderabad, India, 1980; pp 93-102.

Jackson, M. A.; Stewart, J. N.; Peterson, R. E.; Slininger, P. $J$. Fusarin $C$ purification and measurement ip submerged cultures of Fusarium moniliforme by high-performance liquid chromatography. J. Agric. Food Chem. 1990, 38, 1511-1514.

Jambunathan, R.; Kherdekar, M. S. Flavan-4-ols concentration in leaf tissues of grain mold susceptible and resistant sorghum plants at different stages of leaf development. $J$. Agric. Food Chem. 1991, 39, 1163-1165.

Jambunathan, R.; Butler, L. G.; Bandyopadhyay, R.; Mughogho, L. K. Polyphenol concentration in grain, leaf, and callus tissues of mold-susceptible and mold-resistant sorghum cultivars. J. Agric. Food Chem. 1986, 34, 425-429.

Jambunathan, R.; Kherdekar, M. S.; Bandyopadhyay, R. Flavan-4-ols concentration in mold-susceptible and mold- resistant sorghum at different stages of grain development. J. Agric. Food Chem. 1990, 38, 545-548.

Jambunathan, R.; Kherdekar, M. S.; Vaidya, P. Ergosterol concentration in mold-susceptible and mold-resistant sorghum at different stages of grain development and its relationship to flavan-4-ols. J. Agric. Food Chem. 1991, 39, 1866-1870.

Jambunathan, R.; Kherdekar, M. S.; Stenhouse, J. W. Sorghum grain hardness and its relationship to mold susceptibility and mold resistance. J. Agric. Food Chem. 1992, 40, 1403-1308.

Karahadian, C.; Josephson, D. B.; Lindsay, R. C. Volatile compounds from penicillium sp. contributing musty-earthy notes to brie and camembert cheese flavors. J.Agric. Food Chem. 1985, 33, 339-343.

Munsell Book of Color; Macbeth and Photometry Division of Kollmorgan: Baltimore, MD, 1989.

Seifert, R. M.; King, A. D., Jr. Identification of some volatile constituents of Aspergillus clavatus. J. Agric. Food Chem. 1982, 30, 786-790.

Seitz, L. M.; Sauer, D. B.; Burroughs, R.; Mohr, H. E.; Hubbard, J. D. Ergosterol as a measure of fungal growth. Phytopathology 1979, 69, 1202-1203.

Shane, W. W., Joyner, T. G.; Powell, C. C. APPLICAL, RANDOMA and MULTISTAT; Three micro computer utilities for managing field trials. Plant Dis. 1990, 74, 333-334.

Sydenham, E. W.; Shepard, G. S.; Thiel, P. G.; Marasas, W. F. O.; Stockenstrom, S. Fumonicin contamination of commercial corn based human foodstuffs. J. Agric. Food Chem. 1991, 39, 2014-2018.

Young, C. T.; Hovis, A. R. A method for the rapid analysis of headspace volatiles of raw and roasted peanuts. J. Food Sci. 1990, 55, 279-280.

Received for review October 4, 1993. Revised manuscript received September 27, 1994. Accepted October 8, 1994.`

JF930527D

${ }^{\otimes}$ Abstract published in Advance ACS Abstracts, November 15, 1994. 